Külgazdaság, LXIII. évf., 2019. szeptember-október (102-108. o.)

\title{
Hol van a sértett érdekeinek a központja? Jogi személyek személyiségi jogainak sérelme weboldalon keresztül: a Bolagsupplysningen-ügy VINCZE GABRIELLA ANITA
}

Az elmúlt években számos olyan ügy került az Európai Unió Bírósága (EUB) elé, amelyekből kiviláglanak az internetes technológia által lehetövé tett, az online platformok felvirágzásával fokozódó adatáramlás és az uniós joghatósági és kolliziós jogi rendeletek által felállított szabályrendszer közötti súrlódások. Az EUB 2017-es döntése újabb mérföldkövet jelent a polgári és kereskedelmi ügyekben joghatósági szabályokat tartalmazó Brüsszel-rendeletsorozat joggyakorlatában, az interneten keresztül elkövetett személyiségi jogok megsértése és a jogellenes károkozással kapcsolatos joghatósági szabályok értelmezésében. A tanulmány a Bolagsupplysningen-ügyröl nyújt áttekintést.*

Journal of Economic Literature (JEL) kód: K19.

* Köszönöm $d r$. Raffai Katalinnak a tanulmány elkészítéséhez nyújtott támogatását és szakmai észrevételeit.

https://doi.org/10.47630/KULG.2019.63.9-10.102

Vincze Gabriella Anita, doktoranda, megbízott oktató, Pázmány Péter Katolikus Egyetem Jog- és Államtudományi Kar, Nemzetközi Magánjogi Tanszék. E-mail: vincze.gabriella.anita@jak.ppke. 
Hol van a sértett érdekeinek a központja? Jogi személyek személyiségi jogainak...

\section{Tényállás és megválaszolandó kérdések}

Ez az eset a polgári és kereskedelmi ügyekben a joghatóságról, valamint a határozatok elismeréséről és végrehajtásáról szóló Brüsszel Ia. rendelet ${ }^{1}$ 7. cikk 2. pontja - a jogellenes károkozásra vagy a jogellenes károkozással egy tekintet alá eső cselekményre vonatkozó különös joghatóság értelmezésével kapcsolatban, a Shevill- és az eDate-Martinez-ügyek nyomán megalapozott gyakorlathoz ad újabb adalékot az online média és a jogi személyek vonatkozásában.

A tényállás szerint a Bolagsupplysningen ${ }^{2}$ észt jog szerint létrejött társaság és annak alkalmazottja, I. Ilsjan (felperesek) 2015. szeptember 29én keresetet indított a Svensk Handel, a kereskedelmi ágazatban müködő munkáltatókat egyesítő, svéd jog szerint létrejött társaság (alperes) ellen a harjui elsőfokú bíróság (Észtország) előtt.

A felperesek azt kérték, a bíróság kötelezze a Svensk Handelt az internetes oldalán a Bolagsupplysningen vonatkozásában közzétett valótlan állítások helyreigazítására és az ott szereplő hozzászólások eltávolítására, a Bolagsupplysningen részére kártérítés megfizetésére és a bíróság értékelése alapján az I. Ilsjan által elszenvedett nem vagyoni kár jogos megtérítésére.

A svéd alperes társaság ugyanis az internetes oldalán felvette a Bolagsupplysningent egy ún. 'feketelistára', annak feltüntetésével, hogy e társaság csalárd és megtévesztő cselekményeket követ el.

Az említett oldalon volt egy fórum is, amely hozzávetőleg 1000 hozzászólást tartalmazott, köztük a Bolagsupplysningennel és alkalmazottaival szembeni eröszakos cselekményekre történő közvetlen felhívást is. Az alperes megtagadta ezen feljegyzés és az említett hozzászólások eltávolítását, ami a felperesek állitása szerint megbénította a Bolagsupplysningen svédországi gazdasági tevékenységét, mivel ebből kifolyólag a társaság napi szinten anyagi kárt szenvedett.

A harjui elsőfokú bíróság szerint nem volt alkalmazható a Brüsszel Ia. rendelet 7. cikkének 2. pontja, mert a keresetlevélből nem derült ki, hogy a kár Észtországban következett be.

A vitatott állításokat és hozzászólásokat svéd nyelven tették közzé, és azok az Észtországban élő személyek számára fordítás nélkül nem érthetőek. A szóban forgó

${ }^{1}$ Az Európai Parlament és Tanács 1215/2012/EU rendelete (2012. december 12.) a polgári és kereskedelmi ügyekben a joghatóságról, valamint a határozatok elismeréséről és végrehajtásáról. (Brüsszel Ia. rendelet). HL L 2012.12.20.

${ }^{2}$ C-194/16. Bolagsupplysningen OÜ, Ingrid Ilsjan kontra Svensk Handel AB sz. ügy [ECLI:EU:C:2017:766]. Lásd: http://curia.europa.eu/juris/document/document.jsf?text=\&docid=19558 $3 \&$ pageIndex $=0 \&$ doclang $=$ HU\&mode $=1$ st $\& \operatorname{dir}=\& o c c=$ first $\&$ part $=1 \& \operatorname{cid}=11462762$ 
állitások megértése a nyelvi háttértől függ. Nem bizonyították, hogy a kár Észtországban következett be, és a forgalom svéd koronában történő feltüntetése arra enged következtetni, hogy e kárt Svédországban okozták. Az a körülmény, hogy a vitatott internetes oldal hozzáférhető Észtországban, nem igazolhatja automatikusan, hogy észt bíróságnak kell döntenie a polgári ügyben.

A másodfokú bíróság ezt helybenhagyta, de az ügy továbbment, és a harmadfokú fellebbviteli bíróság terjesztette az EUB elé előzetes döntéshozatali eljárás keretében.

Legfőképpen a Brüsszel Ia. rendelet 7. cikk 2. pontjában található párhuzamos joghatósági ok 'annak a helynek a birósága elött, ahol a káresemény bekövetkezett vagy bekövetkezhet' fordulat értelmezése állt a tagállami bíróság kérdéseinek középpontjában.

Egyrészt, vajon a sérelmet szenvedett fél indíthat-e keresetet bármely olyan tagállam bírósága előtt, amelynek területén hozzáférhető vagy hozzáférhető volt az interneten közzétett információ, az e tagállamban keletkezett kár tekintetében a valótlan állítások helyreigazítása és a jogait sértő hozzászólások eltávolítása iránt?

Másrészt, a valótlan állítások közzétételével sérelmet szenvedett jogi személy a számára okozott teljes kár tekintetében követelheti-e az érdekeinek központja szerinti állam fóruma előtt az állítások helyreigazítását, a hozzászólások eltávolítására való kötelezést és a valótlan állítások interneten történő közzétételével okozott vagyoni kár megtérítését?

\section{Egy, az ügy kapcsán megválaszolandó kérdés: rendelkeznek-e a jogi személyek személyiségi jogokkal?}

Az eljárás folyamán felmerült egy újszerü kérdés: a jogi személyekre is kiterjeszthetők-e a személyiségi jogok mint alapvető jogok védelme? Bár ennek az előzetes kérdésnek a megválaszolása a döntés meghozatala szempontjából nem bizonyult nélkülözhetetlennek, Michal Bobek főtanácsnok indítványa ${ }^{3}$ mégis jelentős mértékben foglalkozott vele.

Rendelkezneke, rendelkezhetnek-e a jogi személyek személyiségi jogokkal?

${ }^{3}$ Michal Bobek fötanácsnok indítványa C194/16. sz. ügy Bolagsupplysningen OÜ Ingrid Ilsjan kontra Svensk Handel AB [ECLI:EU:C:2017:554], 36-69. pont. Lásd: http://curia.europa.eu/juris/ document/document.jsf;jsessionid=9ea7d0f130d57ebe16fba98740eea03ccdbb212bd5e3.e34KaxiLc3e Qc40LaxqMbN4PaNiPe0?text $=\&$ docid $=192713 \&$ pageIndex $=0 \&$ doclang $=$ HU\&mode $=1$ st \&dir $=\&$ occ $=$ first\&part=1\&cid=1214867 
Hol van a sértett érdekeinek a központja? Jogi személyek személyiségi jogainak...

Az ügyben részt vevő felek eltérő álláspontokat képviseltek a témában. Az észt kormány például többször kifejtette, hogy a védelmet élvező személyiségi jogok jellegüknél és hatásuknál (fájdalom, szenvedés) fogva kizárólag a természetes személyeket illethetik meg, míg más megfogalmazásban, de az Egyesült Királyság és a Bizottság is hasonló véleményeknek ${ }^{4}$ adott hangot. A felszólalókkal szemben Bobek főtanácsnok ellenkező következtetésre jutott, amikor hangsúlyozta, hogy az ügy szempontjából nem is a társaságok alapvető jogainak terjedelmére vonatkozó vitának van kulcsfontosságú szerepe, hanem inkább annak eldöntésének, hogy a különös joghatósági okok - mint jelen esetben a Brüsszel Ia. 7. cikk (2) bekezdése - felmerülése esetén indokolt-e eltérően kezelni a természetes és jogi személyeket.

A fötanácsnoki vélemény egyértelműen rögzítette, hogy nem látja alátámaszthatónak ezt a különbségtételt, különösen a természetes személy mint a jogi személyekkel szembeni 'gyengébb fél' javára. A jelentős sérelem, amely valamely tartalom interneten történő közzétételével azonnal megvalósulhat, nem indokolja a joghatósági szabályok kizárólag a természetes személyek javára kedvező értelmezését, föleg hogy a Brüsszel Ia. rendelet 7. cikk 2. pontjában szereplő joghatósági szabálynak nem célja a gyengébb fél védelme. A gyengébb fél védelmére irányuló célkitűzést a rendeletben található, a fogyasztókra, munkavállalókra és a biztosítási ügyekkel kapcsolatos bizonyos meghatározott személyekre vonatkozó speciális joghatósági szabályok teljesítik. A főtanácsnok álláspontja szerint a jogellenes károkozással kapcsolatos ügyekre vonatkozó különös joghatósági szabály inkább a követelés és az annak elbirálására hatáskörrel rendelkezö bíróság közötti szoros kapcsolaton alapul.

\section{A Bolagsupplysningen-ügyben született döntés helye az EUB-nak a személyiségi jogsértések körében hozott döntései sorában}

Bár az eDate-Martinez-ügy során az EUB már az online jogsértésekhez igazította a kapcsolódási szempontokat, lehetővé téve a károsultnak, hogy a teljes kártérítésért az érdekeinek központja szerinti fórumon is perelhessen, nem határozta meg

${ }^{4}$ Az Egyesült Királyság szerint az interneten közzétett káros hatású tartalmak miatt igényelt kártérítés a valóságban egybeesik a jogi személyek által elszenvedett kereskedelmi veszteséggel, amely eltérö kérdéseket vet fel, mint amelyek a természetes személy jó hírnevének megsértése esetén felmerülnek. A Bizottság mindössze azt hangsúlyozta, hogy az érdekek központján alapuló forum actorist nem szabad kiterjeszteni a jogi személyekre, mert egy ilyen kiterjesztés nem felelne meg a szóban forgó érdekek közötti egyensúlynak. 
részletesen, hogy hogyan kell értelmezni ezt a központot, ${ }^{5}$ legalábbis jogi személyek esetén, illetve milyen tényezőket kell figyelembe venni ennek megállapításához. Mindez bővebben kifejtésre került a Bolagsupplysningen-ügyben.

Azon kívül, hogy az ügyben szereplő felek jogi személyek voltak, jelentős tényállási elemként jelenik meg, hogy a károsult gazdasági tevékenysége az alapító okiratában megjelölt székhelyétől eltérő tagállamra irányultak.

Hogyan állapítható meg az ilyen sértett érdekeinek központja a Brüsszel Ia. rendelet 7. cikk 2. pontjának megfelelöen?

Az EUB épített az eDate Advertising-ítéletben kimondottakra, rámutatva, hogy természetes személyek esetében az érdekek központja a lakóhely szerinti államon kívül olyan államban is megalapozott lehet, ahol, bár a személy nem rendelkezik lakóhellyel, egyéb ténykörülmények, mint például valamely szakmai tevékenység gyakorlása az ezen állammal való szoros kapcsolatra utalhatnak. ${ }^{6}$

Ezzel párhuzamot vonva valamely jogi személy székhelye, annak elhelyezkedése önmagában nem számít döntő szempontnak, a hangsúly a felperes gazdasági tevékenységére, annak túlnyomó része elvégzésének helyére kerül, mert ez lesz az a hely, ahol az üzleti jó hírnév leginkább megalapozott és megsérthető.

Amennyiben tehát, mint az alapügyben is, az érintett jogi személy tevékenységeinek legnagyobb részét a létesítő okirat szerinti székhelyének tagállamától eltérő tagállamban gyakorolja, feltételezni kell, hogy e jogi személy üzleti jó hírneve, amelyet a szóban forgó közzététel érinthet, e tagállamban jelentősebb, mint bármely más tagállamban, és hogy ennek következtében ott az említett jó hírnév sérelme is fokozottabban érzékelhető.

Ami a nyelvi megfogalmazást és a felperes szakmai tevékenységének központi államában (Svédország) fenntartott szakmai oldalon való közzétételt illeti, ebből arra lehet következtetni az EUB szerint, hogy a valótlan vagy jó hírnevet sértő megjegyzéseket arra szánták, hogy az ebben az államban élő személyek, akikre a társaság tevékenységének túlnyomó része kiterjed, megértsék őket. ${ }^{7}$

Ennek következtében az említett tagállam bíróságai a legalkalmasabbak ezen állítólagos jogsértés fennállásának és esetleges terjedelmének megítélésére.

${ }^{5}$ „Azon hely, ahol valamely személy érdekeinek központja található, általában a szokásos lakóhelyének felel meg. Valamely személy érdekeinek központja azonban olyan tagállamban is lehet, ahol e személy nem rendelkezik szokásos lakóhellyel, amennyiben más ténykörülmények, úgymint valamely szakmai tevékenység gyakorlása, az ezen állammal való különösen szoros kapcsolatra utalhatnak.” Lásd: eDate Advertising GmbH kontra X (C-509/09) és Olivier Martinez és Robert Martinez kontra MGN Limited (C-161/10) egyesített ügyek, [ECLI:EU:C:2011:685], 49. pont.

${ }^{6}$ Lásd: eDate-Martinez ítélet 49. pont.

${ }^{7}$ Bolagsupplysningen-ítélet, 41-42. pont. 
Hol van a sértett érdekeinek a központja? Jogi személyek személyiségi jogainak...

A kérdés újszerüségét illusztrálja, hogy a korábbi ítélkezési gyakorlatban kialakított elvekhez képest a jogalkalmazó azzal kénytelen szembesülni, hogy az internet alapjaiban változtatta meg a közzétételre vonatkozó szabályokat, mintegy demokratizálva azokat. Többé nem állja meg a helyét a feltételezés, hogy a felperes valószínủleg gyenge magánszemély, míg az alperes az 'erős' hivatásos kiadó. Bármely természetes személy könnyedén tehet közzé bármilyen (esetlegesen jogsértő) tartalmat, függetlenül attól, hogy az jogi vagy természetes személyre, illetve közigazgatási hatóságra vonatkozik.

\section{Következtetések}

Az EUB tehát az eDate-Martinez-ügy nyomvonalán haladva továbbfejlesztette a 'sértett érdekeinek központja' elvet és pontosította a Brüsszel Ia. rendelet 7. cikk (2) bekezdésébe foglalt párhuzamos joghatósági szabálya alapján a kereset elbírálására joghatósággal rendelkező fórumok körét.

Szakított viszont a Shevill-ügyben ${ }^{8}$ kifejlesztett, és az eDate-Martinez-esetben fenntartott ún. mozaikelvvel. Utóbbi elv alapján a felperes - érdekeinek központján és a tartalom közzétevőjének letelepedési helyén kívül - megindíthatta kártérítési keresetét bármely állam fóruma előtt, ahol a vitatott sajtócikk vagy jó hírnevet sértő állítás közzététele megvalósult. Azonban ez a bíróság kizárólag az ebben az államban okozott kár elbírálására rendelkezik joghatósággal, nem dönthet a teljes kár megtérítéséröl.

Az EUB határozott nemet mondott a mozaikelv alkalmazására a Bolagsupplysningen-ügyben.

A személyhez füződő jogokat sértő, internetes oldalon közzétett állítások és tartalmak helyesbítésére és a hozzájuk tartozó hozzászólások törlésére irányuló kérelem az EUB álláspontja szerint egy és oszthatatlan, ezért csak olyan bíróság előtt terjeszthető elő, amely teljes kártérítési kereset elbírálására joghatósággal rendelkezik, olyan bíróság elött azonban nem, amely ilyen joghatósággal nem rendelkezik. ${ }^{9}$

Mindezt az online tartalmak mindenütt jelenvaló jellege és az a körülmény indokolja, hogy a közzétett tartalom a világ bármely országából hozzáférhető. Az EUB törekvése a mozaikelvtől való elfordulásra szakmai körben kedvező fogadtatásra talált, mivel régóta problémásnak ítélték ennek a megoldásnak a gyakorlati alkalma-

${ }^{8}$ Lásd: C-68/93 Fiona Shevill, Ixora Trading Inc, Chequepoint SARL és Chequepoint International Ltd kontra Presse Alliance SA. sz. ügy [ECLI:EU:C:1995:61].

${ }^{9}$ Lásd: Bolagsupplysningen-ítélet, 48-49. pont. 
zását és a versengő joghatóságok felállítását, többen a Brüsszel Ia. rendelet céljainak való ellentmondást láttak benne. ${ }^{10}$ Kérdés, hogy vajon továbbra is ebbe a - sokak szerint korszerübb - irányba halad-e tovább az EUB? Erre talán a folyamatban lévő Glawischnig-Piesczek kontra Facebook Ireland Limited-ügy ${ }^{11}$ eldöntése után kaphatunk majd választ.

\section{Irodalomjegyzék}

1. C-194/16. Bolagsupplysningen OÜ, Ingrid Ilsjan kontra Svensk Handel AB sz. ügy [ECLI:EU:C:2017:766]. Letölthetö: http://curia.europa.eu/juris/document/document.jsf?text=\&d ocid=195583\&pageIndex $=0 \&$ doclang $=H U \&$ mode $=1$ st\&dir $=\& o c c=$ first\&part $=1 \& c i d=11462762$

2. Az Európai Parlament és Tanács 1215/2012/EU rendelete (2012. december 12.) a polgári és kereskedelmi ügyekben a joghatóságról, valamint a határozatok elismeréséről és végrehajtásáról. (Brüsszel Ia. rendelet) HL L 2012.12.20. Letölthető: https://eur-lex.europa.eu/legal-content/HU/ TXT/?uri=CELEX\%3A32012R1215

3. Michal Bobek fötanácsnok indítványa C194/16. sz. ügy Bolagsupplysningen OÜ Ingrid Ilsjan kontra Svensk Handel AB, [ECLI:EU:C:2017:554]. Letölthető: http://curia.europa.eu/juris/document/ document.jpf;jsessionid=9ea7d0f 130d57ebe16f ba98740eea03ccdbb212bd5e3.e34KaxiLc3eQc40 LaxqMbN4PaNiPe0?text $=\&$ docid $=192713 \&$ pageIndex $=0 \&$ doclang $=$ HU\&mode $=1 \mathrm{st} \&$ dir $=\& o c c=$ first\&part $=1 \&$ cid $=1214867$

4. C-68/93. Fiona Shevill, Ixora Trading Inc, Chequepoint SARL és Chequepoint International Ltd kontra Presse Alliance SA.sz. ügy [ECLI:EU:C:1995:61]. Letölthető: http://curia.europa.eu/juris/ liste.jsf?language $=$ hu\&num $=\mathrm{C}-68 / 93$

5. eDate Advertising GmbH kontra X (C-509/09) és Olivier Martinez és Robert Martinez kontra MGN Limited (C-161/10) egyesített ügyek [ECLI:EU:C:2011:685]. Letölthető: http://curia.europa.eu/ juris/document/document.jsf;jessionid=956DF718520E64BE92C9300C33C49EF2?text=\&docid $=130827 \&$ pageIndex $=0 \&$ doclang $=$ hu $\&$ mode $=$ req $\&$ dir $=\&$ occ $=$ first \&part $=1 \& c i d=1136682$

6. Lutzi, Tobias [2017]: Internet cases in EU Private International Law-Developing a coherent approach. Letölthető: $\quad$ https://www.cambridge.org/core/journals/international-and-comparative-lawquarterly/article/internet-cases-in-eu-private-international-lawdeveloping-a-coherent-approach/ D0A2620AFC178147DCBFB7CCA394FC2D

7. Vincze Gabriella Anita [2019]: Joghatósági kihívások a digitális korban - Az interneten elkövetett személyiségi jogi jogsértések legújabb fejleményei az EUB előtt. Ünnepi kötet Burián László 65. születésnapja alkalmából (megjelenés alatt).

8. Jütte, Justin [2017]: Mere accessibility of a website does not trigger jurisdiction for injunctions when personality rights are infringed (ECJ, C-194/16, Bolagsupplysningen/Ilsjan). Letölthetö: https:// europeanlawblog.eu/2017/12/06/mere-accessibility-of-a-website-does-not-trigger-jurisdictionfor-injunctions-when-personality-rights-are-infringed-ecj-c-19416-bolagsupplysningenilsjan/

${ }^{10}$ Tobias Lutzi: Internet cases in EU Private International Law-Developing a coherent approach. Lásd: https://www.cambridge.org/core/journals/international-and-comparative-law-quarterly/article/internet-cases-in-eu-private-international-lawdeveloping-a-coherent-approach/ D0A2620AFC178147DCBFB7CCA394FC2D

${ }^{11}$ Eva Glawischnig-Piesczek kontra Facebook Ireland Limited, C-18/18. sz. folyamatban lévő ügy. Jelenleg még nincs ECLI EU száma. 